\title{
Entrepreneurial Behaviour of Dairy Farmers
}

\author{
B. Bhanuprakash Reddy ${ }^{1 *}$, G. Triveni ${ }^{2}$, G. R. K. Sharma ${ }^{3}$, \\ Y. Ravindra Reddy ${ }^{4}$ and M. A. Harisha ${ }^{5}$
}

SVVU, Tirupati, Andhra Pradesh, India

*Corresponding author

\section{A B S T R A C T}

Keywords

Dairy Farmers, Entrepreneurship, Entrepreneurial behaviour index

Article Info

Accepted: 14 April 2021 Available Online: 10 May 2021
Dairy enterprise is recognized to play a constructive role in reducing poverty and promoting rural welfare at farm level. Considering the need for development of entrepreneurship among dairy farmers a study was conducted in Chittoor district of Andhra Pradesh to know the level of entrepreneurial behavior of dairy farmers. A sample of 160 respondents was selected from four mandals of chittoor district of A.P. The data were collected through pre-tested structured interview schedule by holding personal interview with dairy farmers during the year 2018-2019.The study revealed that majority of dairy farmers had medium level of innovativeness (59.40\%), decision making ability (55.60\%), planning ability $(50.00 \%)$, cosmopoliteness $(68.80 \%)$ and low level of self-confidence $(41.20 \%)$. The Entrepreneurial behaviour index for overall entrepreneurial behavior was found to be 79.01 .

\section{Introduction}

India is one of the most populated countries in the world. Poverty and unemployment are the major problems of rural India. Human resource is one of the most strategic and critical determinants of growth. It is the contribution of people with entrepreneurial urge that makes a nation to march ahead in the process of development. Livestock sector plays an important role in Indian economy and is an important subsector of Indian agriculture.
The future progress of dairy sector in the country depends on the ability the dairy farmers to transform it into a profitable enterprise.

Entrepreneurship development among dairy farmers ensures optimal utilization of resources and facilitates value addition to products and services.

Considering the need for development of entrepreneurship among dairy farmers, it is 
felt necessary to measure the entrepreneurial behavior of dairy farmers since dairy enterprise is recognized to play a constructive role in reducing poverty and promoting rural welfare at farm level.

\section{Materials and Methods}

The present study was conducted in the state of Andhra Pradesh. Chittoor district was purposively selected for the study owing to its highest milk production in the state, large number of primary milk producers and a good network of milk procurement centres. Chittoor district is divided into four animal husbandry divisions namely Chittoor, Madanapalle, Tirupati and Puttur.

One mandal from each animal husbandry division and two villages from each mandal were selected based on highest number of cattle population in that division. Finally four mandalsie., G.D Nellore from Chittoor division; Peddatippasamudram (PTM) from Madanapalle division; Chinnagottigallu from Tirupati division and Srikalahasti from Puttur division were selected purposively, resulting in eight villages from four animal husbandry divisions of the district. The criteria for identification of potential dairy entrepreneurs were based on the following conditions. Individual dairy farmer must possess 3 milch animals and above.

The dairy farmer must sell at least 10 litres of milk per day.

The dairy farmer should sell more than 60 per cent of produced milk per day to the market.

Twenty respondents from each of the eight villages were selected using simple random sampling technique comprising a total sample 160 respondents for the study. The entrepreneurial behaviour of dairy farmers was measured in terms of five dimensions namely; innovativeness, decision-making ability, Planning ability, cosmopoliteness and self-confidence.

The farmers were subjected to the semi structured interview schedule and responses collected were empirically analyzed with standard statistical measures to know the entrepreneurial behavior. Entrepreneurial behaviour index (EBI) was also calculated by using formula:

Entrepreneurial behaviour index $(\mathrm{EBI})=$ Obtained mean score/Maximum obtainable score $\mathrm{x} 100$

\section{Results and Discussion}

Majority (66.90\%) of dairy farmers had medium level followed by low $(20.00 \%)$ and high (13.10\%) level of entrepreneurial behaviour. Similar findings were reported by Mariammal and Seethalakshmi (2017), Jaisawal and Patel (2012) and Kiran et al., (2012).

\section{Components of entrepreneurial behaviour of dairy farmers}

Five components of entrepreneurial behaviour of the farmers were measured and the result is presented in table 3 as follows.

\section{Innovativeness}

Majority (59.40\%) of dairy farmers had medium level of innovativeness while 21.8 and 18.8 per cent of dairy farmers had high and low levels of innovativeness, respectively. This could be due to the fact that limited awareness on new technologies and skills, poor literacy, rigid beliefs and confined habits of the dairy farmers might have prevented them from being innovative in trying out new technologies. These results are in accordance with finding of Avhad et al., (2014). 


\section{Decision-making ability}

As evident from table 2, more than half $(55.60 \%)$ of the respondents had medium level of decision making ability followed by 34.4 and 10 per cent of respondents with low and high levels of decision making ability, respectively. This might be due to medium level of education and experience which might have facilitated them to change foresight and confidence and opted them to choose good among available alternatives. These results are in accordance with findings of Ram et al., (2013).

\section{Planning ability}

Indicated that exactly half $(50.00 \%)$ of the dairy farmers had medium level of planning ability whereas 36.3 and 13.7 per cent of dairy farmers had low and high levels of planning ability, respectively. The probable reason is their varied education levels and medium income from dairying. Usually farmers with large herd size, large land holding and capital will naturally have resourcefulness in carrying out quicker decision towards planning dairy management practices. These results are in accordance with findings of Lawrence and Ganguli (2012) and Patel et al., (2014).

\section{Cosmopoliteness}

Majority $(68.80 \%)$ of the dairy farmers had medium level of cosmopoliteness followed by 23.1 and 8.1 per cent of dairy farmers with low and high level of cosmopoliteness, respectively.

The above trend shows that, dairy farmers have attempted to keep contact with external social system and thus extend the extension contact with various extension agencies out of their social system.

\section{Self confidence}

Higher proportion $(41.20 \%)$ of the respondents possessed low level of this trait, whereas 34.4 and 24.4 per cent of respondents had medium and high level of self-confidence, respectively. This might be due to the fact that, they were not confident about their abilities to improve their dairy enterprise and were not much successful in running a dairy enterprise. These results are in accordance with findings of Raut and Sankhla (2014).

\section{Entrepreneurial Behaviour Index (EBI)}

The entrepreneurial behaviour index (EBI) indicates the extent to which an individual is possessing this attribute. The results after application of the formula for entrepreneurial behavior index were described in table 2 .

It is evident from table 2 that highest EBI 83.62 was found with planning ability and so ranked first, while the lowest index of 74.57 was recorded in the decision making ability and ranked last among five attributes of entrepreneurial behavior.

However the EBI of other attributes such as innovativeness, cosmopoliteness, selfconfidence was $83.60,78.38$ and 81.62 respectively. The EBI for overall entrepreneurial behavior was found to be 79.01 .

The plausible reasons for securing I and II ranks for planning ability and innovativeness might be due to medium level of education, medium herd size, medium financial condition and medium level of knowledge about improved dairy management practices. Dairy entrepreneurs could not venture to take quicker decisions or options for the fear of incurring losses in their dairy enterprise. 
Table.1 Distribution of respondents according to their overall entrepreneurial behavior

\begin{tabular}{|c|c|c|c|}
\hline S.No & Category & Frequency & Percentage \\
\hline $\mathbf{1}$ & Low & 32 & 20.00 \\
\hline $\mathbf{2}$ & Medium & 107 & 66.90 \\
\hline $\mathbf{3}$ & High & 21 & 13.10 \\
\hline & Total & 160 & 100.00 \\
\hline \multicolumn{2}{|c|}{ Mean $\mathbf{5 1 . 3 6}$} & \multicolumn{2}{|c|}{ S.D $=4.55$} \\
\hline
\end{tabular}

Table.2 Extent of entrepreneurial behavioral attributes possessed by dairy farmers

\begin{tabular}{|c|c|c|c|c|}
\hline S.No & Attributes & Mean & EBI & Rank \\
\hline $\mathbf{1}$ & Innovativeness & 8.36 & 83.60 & II \\
\hline $\mathbf{2}$ & Decision making ability & 15.66 & 74.57 & V \\
\hline $\mathbf{3}$ & Planning ability & 6.69 & 83.62 & I \\
\hline $\mathbf{4}$ & Cosmopoliteness & 14.11 & 78.38 & IV \\
\hline $\mathbf{5}$ & Self confidence & 6.53 & 81.62 & III \\
\hline & Overall entrepreneurial & 51.36 & 79.01 & - \\
\hline
\end{tabular}

Table.3 Distribution of dairy farmers based on components of entrepreneurial behaviour of dairy farmers

\begin{tabular}{|c|c|c|c|c|c|c|}
\hline \multicolumn{7}{|c|}{$\begin{array}{ll}(N=160) & (160)\end{array}$} \\
\hline No. & Variables & Categories & Frequency & Percent & Mean & SD \\
\hline \multirow[t]{3}{*}{1.} & \multirow{3}{*}{ Innovativeness } & Low & 30 & 18.80 & 8.36 & 1.04 \\
\hline & & Medium & 95 & 59.40 & & \\
\hline & & High & 35 & 21.80 & & \\
\hline \multirow[t]{3}{*}{2.} & \multirow[t]{3}{*}{ Decision making ability } & Low & 55 & 34.40 & 15.66 & 3.02 \\
\hline & & Medium & 89 & 55.60 & & \\
\hline & & High & 16 & 10.00 & & \\
\hline \multirow[t]{3}{*}{3.} & \multirow[t]{3}{*}{ Planning ability } & Low & 58 & 36.60 & 6.69 & 0.81 \\
\hline & & Medium & 80 & 50.00 & & \\
\hline & & High & 22 & 13.70 & & \\
\hline \multirow[t]{3}{*}{4.} & \multirow[t]{3}{*}{ Cosmopoliteness } & Low & 37 & 23.10 & 14.11 & 1.98 \\
\hline & & Medium & 110 & 68.80 & & \\
\hline & & High & 13 & 8.10 & & \\
\hline \multirow[t]{3}{*}{5.} & \multirow[t]{3}{*}{ Self confidence } & Low & 66 & 41.20 & 6.53 & 1.10 \\
\hline & & Medium & 55 & 34.40 & & \\
\hline & & High & 39 & 24.40 & & \\
\hline
\end{tabular}


It is also a fact, that respondents possess comparatively low amount of inner urge to improve themselves and excel their dairy enterprise. For successful phenomenon of entrepreneurship this symptom is not encouraging. These reasons resulted in the remaining attributes namely cosmopoliteness, self-confidence and decision making ability to occupy III, IV and V positions respectively.

The study has clearly shown that majority of dairy farmers had medium level of entrepreneurial behavior. In this regard, entrepreneurship development training programme and model training courses must focus more on dairy farmers to venture to take risks and face uncertainties for their prosperous livelihood. Entrepreneurship development interventions such as conducting training programmes through various extension and development agencies in the form of demonstrations, field visits, tours trainings to impart knowledge and motivation must be emphasized.

\section{References}

Avhad, S. R., Kadian, K. S., Verma, A. K. and Kale, R. B. 2014. Entrepreneurial behaviour of dairy farmers in Ahmednagar district of Maharashtra. Indian Agricultural Science Digest, 35 (1): $56-59$.

Chaudhari, R. R., Hirevenkanagoudar, L. V., Hanchinal, S. N., Mokashi, A. N., Katharki, P. A. and Banakar, B. 2007.A scale for measurement of entrepreneurial behaviour of dairy Farmers. Karnataka J. Agril. Sc, 20 (4): 792-796.
Jaisawal, A. and Patel, M. M. 2012. A study on Entrepreneurial behavior of rural Women. Indian Research Journal of Extension Education12(1): 55-59.

Kiran, D. D., Gupta, B. K. and Pandey, D. K. 2012. Entrepreneurial behaviour in rural women of Sultanpur district of Uttar Pradesh. Indian Research Journal of Extension Education12(2): 29-33.

Lawrence, C. and Ganguli, D. 2012. Entrepreneurial behavior of dairy farmers in Tamil Nadu. Indian Research Journal of Extension Education12(1): 66-70.

Mariammal, R. and Seethalakshmi, M. 2017. Entrepreneurial behavior of dairy farm women in Dindigul district of Tamilnadu. International Journal of Science, Environment and technology 6(4): 2539-2547.

Patel. P., Patel, M. M., Badodia, S.K. and Sharma, P. C. 2014.Entrepreneurial behaviour of dairy farmers. Indian Research Journal of Extension Education14 (2):46-49.

Ram. D., Singh, M. K., Chaudhary, K. P. and Jayarani, L. 2013. Entrepreneurship behaviour of women entrepreneurs in Imphal of Manipur. Indian Research Journal of Extension Education13(2): 31-35.

Raut, A. A. and Sankhla, G. 2014. Entrepreneurship among commercial dairy farmers in Maharashtra. Indian journal of Dairy Science 67(6): 535-540.

Sharma, G. R. K., Deekshit, G. V. and Channappagouda, B. 2016. Entrepreneurial behavior of dairy farmers in Chittoor district of Andhra Pradesh. Indian Journal of Agriculture Business, 2(2): 93-96.

\section{How to cite this article:}

Bhanuprakash Reddy, B., G. Triveni, G. R. K. Sharma, Y. Ravindra Reddy and Harisha, M. A. 2021. Entrepreneurial Behaviour of Dairy Farmers. Int.J.Curr.Microbiol.App.Sci. 10(05): 507511. doi: https://doi.org/10.20546/ijcmas.2021.1005.058 